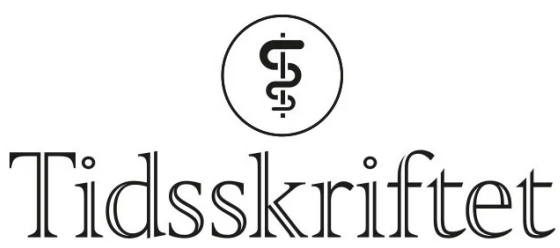

DEN NORSKE LEGEFORENING

\title{
Tvang kan være god omsorg
}

\section{LEDER}

\section{TRUDE FIXDAL}

trudefix@start.no

Trude Fixdal er spesialist i psykiatri og barne- og ungdomspsykiatri og avdelingsleder ved Barne- og ungdomspsykiatrisk poliklinikk (BUP Vest) ved Diakonhjemmet Sykehus.

Forfatteren har fylt ut ICMJE-skjemaet og oppgir ingen interessekonflikter.

\section{HARALD AULIE}

Harald Aulie er psykologspesialist og enhetsleder ved Allmennpsykiatrisk poliklinikk ved Diakonhjemmet Sykehus.

Forfatteren har fylt ut ICMJE-skjemaet og oppgir ingen interessekonflikter.

\section{For enkelte pasienter er tvang riktig omsorg og nødvendig for å gjennomføre behandling til beste for pasienten. Vi trenger en mer nyansert debatt om bruk av tvang i psykisk helsevern.}

Det regjeringsoppnevnte Tvangslovutvalget leverte 18.6.19 sitt forslag til ny tvangslov (1). Deres mandat var å «foreta en samlet gjennomgang og utrede behov for revisjon og modernisering av reglene om bruk av tvang i helse- og omsorgssektoren». Forslaget var på 813 sider og tok til orde for en omfattende innstramming av muligheten til bruk av alle former for tvang overfor barn og personer med psykiske helseproblemer, rusavhengighet, nedsatt funksjonsevne eller demens. I den etterfølgende høringsrunden kom det tydelig frem at målet om redusert bruk av tvang var ukontroversielt.

Likevel møtte forslaget kritikk fra flere hold. Legeforeningen var i sitt høringssvar kritiske til både den kliniske og den lovmessige forankringen av forslaget, og påpekte, i likhet med flere, at mange av utvalgets forslag fremsto som fjerne fra virkeligheten klinikere opplever (2). I I tillegg var det, etter vår erfaring, mange fagfolk som opplevde at forslaget formidlet en tvil om deres intensjoner - en mistillit til at vi både vil og kan bruke mindre og riktigere tvang. Samtidig vet vi at psykiatrien har benyttet tvang på en måte som har vært krenkende, noe høringssvarene til lovforslaget tydelig viste. Debatten om tvang i psykisk helsevern er derfor både nødvendig og ønsket.

Etter undersøkelse kan en lege i dag kreve innleggelse til tvungent psykisk helsevern eller tvungen observasjon. Det må foreligge begrunnet mistanke om en alvorlig psykisk lidelse, og pasienten må mangle samtykkekompetanse. I tillegg skal frivillig behandling ha vært 
forsøkt eller vurdert som åpenbart formålsløst. Etter undersøkelse av to uavhengige leger kan tvungen behandling etableres i godkjent institusjon.

Det er en vanlig misforståelse at tvungent psykisk helsevern innebærer bruk av tvangsmidler. Tvangsmidler er i lovverket beskrevet som mekaniske tvangsmidler, kortvarig opphold bak stengt dør og kortvarig fastholding samt korttidsvirkende legemidler. Disse tvangsinngrepene kan også vedtas overfor frivillig innlagte i godkjent institusjon.

\section{«Det er en vanlig misforståelse at tvungent psykisk helsevern innebcrer bruk av tvangsmidler»}

Pasient- og brukerorganisasjoner har med rette påpekt at praksisen med tvungent psykisk helsevern uten døgnopphold og med vedtak om tvungen medisinering, ofte med depotinjeksjoner av antipsykotika, er et svært inngripende tiltak. Oppfølgingen av disse pasientene har ikke alltid vært god nok, og mange av dem har gått lenge uten at det er gjort nødvendige vurderinger av om behandlingen er hensiktsmessig eller nødvendig. Medikamentene kan gi plagsomme bivirkninger, og effekten på lang sikt er usikker (3). Eksempler på denne typen tvang vekker naturlig nok sterke følelser. Samtidig vet vi at depotpreparater hjelper mange og bedrer funksjonen på flere områder (4.). Fra klinisk praksis vet vi at brukere også har positive erfaringer med tvang og har opplevd det som nødvendig omsorg og hjelp. Disse stemmene er vanskelige å finne i diskusjonen om tvang $\mathrm{i}$ behandling.

Når departementet nå sender et bearbeidet og spisset forslag på høring, dukker noen av problemene med det opprinnelige dokumentet opp. Premissene for det nye lovverket er, slik vi leser det, langt på vei basert på en oppfatning av at tvang $i$ seg selv ikke er ønskelig. Forslaget bærer preg av å bygge på en ideologi som ikke tar opp i seg en nyansert diskusjon om bruk av tvang som nødvendig for god behandling og noen ganger riktig omsorg for pasienten. En polarisert debatt øker risikoen for at det blir vanskeligere å gjennomføre de gode intensjonene i loven. Forankringen av det opprinnelige lovforslaget i kliniske miljøer var dårlig, og Tvangslovutvalget har etter vår mening fått berettiget kritikk for ikke å inkludere fagpersoner med tilstrekkelig erfaring og kompetanse fra klinisk arbeid. Dermed oppleves deler av de bearbeidede forslagene som lite forenlige med praktisk arbeid i fagfeltet. Kravene til hvordan tjenestene skal gjennomføre det nye lovverket, er også omfattende.

En vellykket implementering av et så omfattende lovverk krever tydelig og god forankring $\mathrm{i}$ fagmiljøene, både hos ledere og klinikere. Det krever kjennskap til status i tjenesten og en tydeligere anerkjennelse av fagområdet og kompleksiteten i pasientens sykdomshistorie. Det krever også en anerkjennelse av at fagfolk har bidratt til reduksjon av tvang og til god pasientbehandling. Faren er at gjennomføringen av det nye lovverket blir oppfattet som et krav eller pålegg som ikke bidrar til bedret pasientbehandling, men som gjør det vanskeligere for både pasienter, pårørende og fagfolk.

\section{«Deler av de bearbeidede forslagene oppleves som lite forenlige med praktisk arbeid i fagfeltet»}

Psykisk helsevern er gjenstand for mye oppmerksomhet blant politikere, medier og allmennheten. Antallet reformer, krav og retningslinjer er stort, og mange har bidratt til bedre tjenester der brukerne har fått større mulighet til å påvirke egen behandling. Dette er også ønsket av fagfolk som har stått bak en del av endringene, blant annet brukerstyrte behandlingstilbud og reduksjon i bruk av mekaniske tvangsmidler. Samtidig har ikke tjenesten fått nødvendige ressurser, verken i poliklinisk behandling der tvang uten døgn forvaltes, eller i døgninstitusjoner. 
«Den gylne regel» virker nokså matt i glansen (5). Innføring av et nytt lovverk uten nødvendige ressurser til både spesialist- og kommunehelsetjenesten virker urealistisk og medfører høyere risiko for at gode intensjoner om mindre tvang mislykkes.

\section{LITTERATUR}

1. NOU 2019:14. Tvangsbegrensningsloven - Forslag til felles regler om tvang og inngrep uten samtykke i helse- og omsorgstjenesten. https://www.regjeringen.no/no/dokumenter/nou-201914/id2654803/?ch=1 Lest 2.11.2021.

2. Den norske legeforening. Høringsuttalelse. NOU 2019:14 Tvangsbegrensningsloven - Forslag til felles regler om tvang og inngrep uten samtykke i helse- og omsorgstjenesten.

https://www.legeforeningen.no/hoeringer/interne/2019/nou-2019-14-tvangsbegrensningslovenforslag-til-felles-regler-om-tvang-og-inngrep-uten-samtykke-i-helse-ogomsorgstjenesten/hoeringsuttalelse/ Lest 2.11.2021.

3. Smedslund G, Siqveland J, Kirkehei I et al. Langtidsbehandling med antipsykotika hos personer med schizofrenispektrumlidelser: en systematisk oversikt. Oslo: Folkehelseinstituttet, 2018. https://www.fhi.no/publ/2018/langtidsbehandling-med-antipsykotika-hos-personer-medschizofrenispektrumli/ Lest 2.11.2021.

4. Høiseth G, Bentsen H. Bruk av antipsykotiske depotinjeksjoner. Tidsskr Nor Legeforen 2012; 132: 301-3. [PubMed][CrossRef]

5. Helsedirektoratet. Den gylne regel. https://www.helsedirektoratet.no/statistikk/samdataspesialisthelsetjenesten/hovedtall Lest 2.11.2021.

Publisert: 4. november 2021. Tidsskr Nor Legeforen. DOI: 10.4045/tidsskr.21.0774

Mottatt 1.11.2021, godkjent 2.11.2021.

(C) Tidsskrift for Den norske legeforening 2023. Lastet ned fra tidsskriftet.no 26. april 2023. 